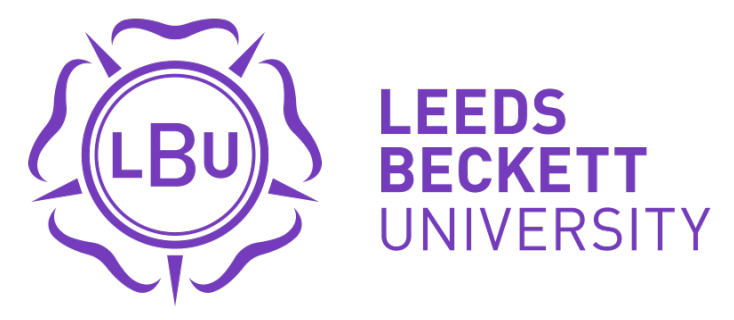

Citation:

Fletcher, TE and Carnicelli, S and Lawrence, S and Snape, R (2017) Reclaiming the 'L' word: Leisure studies and Higher Education in neo-liberal times. Leisure Studies, 36 (2). pp. 293-304. ISSN 0261-4367 DOI: https://doi.org/10.1080/02614367.2016.1261182

Link to Leeds Beckett Repository record:

https://eprints.leedsbeckett.ac.uk/id/eprint/3320/

Document Version:

Article (Accepted Version)

This is an Accepted Manuscript of an article published by Taylor \& Francis in Leisure Studies on 30 November 2016, available online: http://www.tandfonline.com/10.1080/02614367.2016.1261182

The aim of the Leeds Beckett Repository is to provide open access to our research, as required by funder policies and permitted by publishers and copyright law.

The Leeds Beckett repository holds a wide range of publications, each of which has been checked for copyright and the relevant embargo period has been applied by the Research Services team.

We operate on a standard take-down policy. If you are the author or publisher of an output and you would like it removed from the repository, please contact us and we will investigate on a case-by-case basis.

Each thesis in the repository has been cleared where necessary by the author for third party copyright. If you would like a thesis to be removed from the repository or believe there is an issue with copyright, please contact us on openaccess@leedsbeckett.ac.uk and we will investigate on a case-by-case basis. 


\title{
Reclaiming the ' $L$ ' word: Leisure Studies and UK Higher Education in neoliberal times
}

\begin{abstract}
Leisure is a major sphere of both private and public life. It is thus of concern that the identity and profile of Leisure Studies in the Higher Education curricula of the United Kingdom have declined in prominence over the past decade. This trend is not peculiar to Leisure Studies; the social sciences as a whole are threatened by a neoliberal economic discourse which increasingly informs Higher Education strategic management. The aim of this article is to investigate the impacts of the declining status of Leisure Studies as experienced by lecturers and researchers in the subject field. It is based upon a project commissioned by the Higher Education Academy in 2015. It was found that Leisure Studies faces two principal challenges. The first is to re-establish its status as a subject field within the social sciences, the second is to ensure it retains a relevance to leisure practice, particularly in terms of the management of its provision. The article proposes greater academic engagement in ideational 'border crossings' to advance thinking on leisure in the social sciences and to explore opportunities for collaboration within them. We conclude that Leisure Studies arguably suffers from a crisis of representation, as opposed to a crisis of relevance.
\end{abstract}

Key words: Higher Education, Ideational Border Crossings, Leisure Studies, Neo-liberalism, Social Sciences, Vocationalism.

\section{Introduction}

Leisure is important to society for a plethora of reasons. It has individual, social, economic and political value and contributes to quality of life, mental and physical health and the well-being of communities (Such, 2013). In an era when the United Kingdom (UK) government is committed to developing measurements of happiness and well-being (Spiers and Walker, 2009) and in which the consumption of leisure services and goods forms a significant economic sector, it would be difficult to understate the significance of leisure to contemporary society (Roberts, 2016). Given the importance of leisure to social, economic and health policy it is not surprising that leisure features in research undertaken within a range of disciplines and subject fields and has, in the Leisure Studies Association, a learned society within the Academy of Social Sciences. Interest and activity is not confined to the UK but is evident in the United States of America, Canada, Australia, New Zealand and France and is also beginning to form in other countries, notably Brazil and the Netherlands. 
Despite this, the identity and profile of Leisure Studies in UK Higher Education (HE) curricula have become less apparent over the past decade. This decline has been widely noted (Aitchison, 2006; Bramham, 2006; Elkington, 2013; Harris, 2015; Spracklen, 2014) and has created a desire to re-affirm its social and educational importance.

This trend is not peculiar to Leisure Studies; the social sciences as a whole are threatened by a neoliberal economic discourse which increasingly informs HE strategic management. Costefficiencies, utilitarian learning and a turn to the wisdom of 'big data', are among a number of forces positioning the social sciences as 'less germane, inappropriate, and/or undeserving of scholarly attention' (Pike, Jackson and Wenner, 2015: 358). Indeed, as Carrington (2015) warns:

In our neo-liberal age of public sector austerity and instrumental learning, wherein grant-driven scientization and the biomedicalization of research dominates the corporate university, trying to convince undergrads (let alone Deans) to appreciate the relevance of Antonio Gramsci's writings to the sports they love seems nostalgically utopian. (p.393)

For Carrington (2015) and others (e.g., Sparkes, 2013) this devaluing of the social sciences is paradoxical in terms of resolving contemporary social injustices pertaining to ethnicity, gender, sexuality, religion, class and disability. The Academy of Social Science's 'Making the Case for the Social Sciences' and the 'Campaign for Social Sciences' both reflect a perceived imperative to raise the profile of social science teaching, learning and research in the public sphere, particularly in view of an increasing prioritisation of STEM subjects. Indeed, according to Sparkes (2013), the 'turn' towards STEM subjects is being achieved at the expense of the arts, humanities, social sciences through their preferential funding.

There is no single reason for the diminished prominence of Leisure Studies in UK HE curricula. It has been suggested that changed market demand for Sports Studies and Events Management among others has contributed to a fragmentation of Leisure Studies as a subject area as these sub-fields have acquired a sui generis status as subject fields in their own right. The study of leisure has consequently become an increasingly diverse and disjointed collection of curricula (Elkington, 2013). Page and Connell (2010), for example, have linked this to the growth of the cultural and creative industries and the decline of public sector leisure provision, while Henderson (2010) cites disconnect between Leisure Studies and professional practice. Elkington (2013: 448) warns of 'intellectual disconnect' between leisure 'education' and leisure 'practice', which has contributed to a 'crisis of legitimisation for degree programmes with a leisure focus'. The effect of these trends has been to diminish the status of Leisure Studies in academic curricula. As Spracklen (2014: 22) notes: 
Leisure Studies remain within curricula at undergraduate and postgraduate level, and there are a thriving set of sports, events, tourism and hospitality courses that owe their origins to Leisure Studies. But leisure and Leisure Studies seem to be pariah subjects, ignored by senior managers, parents, prospective students and the wider world.

The results of the 2014 Research Excellence Framework (REF) illustrate this point. 2,759 outputs were submitted to Unit 26 (Sport and Exercise Sciences, Leisure and Tourism), an increase of $1.39 \%$ from the previous Research Assessment Exercise (RAE). ${ }^{1}$ However, of those 2,759 only 63 (2.28\%) contained 'leisure' in the title of the publication or the outlet. Perhaps even more striking was that of the 122 impact case studies submitted to Unit 26, only one contained the word 'leisure' in the title. In her keynote address to the Leisure Studies Association annual conference in July 2015, Cara Aitchison outlined the implications of these results, observing that leisure was conspicuous by its absence from the REF 2014 and that the evaluation of submissions had revealed a weakening of the relationship between Leisure Studies and its sub-fields. She argued that the critical mass of Leisure Studies research established during the 1970s and 1980s was neither developing at the same rate nor being sustained, and thus, leisure research was failing to address new global challenges. Furthermore, the increasing disparity between leisure and other sub-fields was also evident in the uneven allocation of funding from research councils.

In response to the trends outlined above, the aim of this article is to investigate the impacts of the reduced presence and status of Leisure Studies in HE curricula in the UK as experienced by academic staff in the field, and to explore how its relevance might be reinstated. In this article Leisure Studies is understood in terms stated in Leisure Studies, the journal of the Leisure Studies Association, as the theoretically informed critical analysis of topics that constitute leisure as a subject field in, for example, the arts, tourism, cultural, informal and virtual activities, urban and rural recreation, sport, media and physical activities. The research for the article was funded through the Higher Education Academy project: 'Teaching and learning in the disciplines' which aimed to gain insight into and understanding of the teaching and learning challenges confronting tutors at a discipline level (Bulman, 2015). The findings of this research are presented below. The next section provides a brief account of the origins and growth of Leisure Studies as a subject field in the UK.

\section{The origins and growth of Leisure Studies}


Leisure Studies finds its origins in the emergence of the social sciences in the nineteenth century. The formation of Leisure Studies as a subject field took place in the nineteen-seventies as the idea of leisure became more important in academic and professional practice circles. From the early nineteen-seventies important sociological works on leisure were published and were followed by interest in the establishment of a learned society to promote research in leisure (Roberts, 1970; Parker, 1971). Interest in leisure was given a further boost through the local government re-organisation of 1974 which created fewer but larger local authorities and led to the establishment of the first leisure services departments which brought together various leisure provisions, such as libraries, museums, parks and swimming baths, under one administrative roof. According to Roberts (2014) national agencies and regional offices including the Sports Council and the Countryside Commission, supported the development of leisure projects and were principal funders and users of research on leisure throughout much of the 1970s. This led to the creation of an academic sub-field, Leisure Management, and a corresponding demand for training and education. The effects of these developments were crucial to the formation of Leisure Studies. First, they led to the provision of a wide range of leisure management-orientated courses in universities and colleges. Second, they enabled an identification of leisure management as a field of professional practice and the formation of a professional association, the Institute of Leisure and Amenity Management, through which several academic courses were certificated. The involvement of academic institutions in this process created a need to undertake research and to develop a rigorous curriculum. According to Andrews (2006) Leisure Studies degree programmes combined three academic strands: a critical sociology, a policy and management core, and practical elements associated with sports and active recreation drawn from physical education. These developments culminated in the formation of the Leisure Studies Association in 1976, which led the way for academic conferences on leisure and the publication of a dedicated journal in Leisure Studies (Kennedy and Pussard, 2006).

In retrospect, the early nineteen-eighties represented the high water mark of Leisure Studies as a holistic field. However, the privatisation of local authority leisure services which curtailed public expenditure on training in Leisure Management and the commodification of post-sixteen education through which Leisure Studies courses were re-designed and re-branded in terms of Sport, Tourism or Events Management reduced demand for degrees in Leisure Studies. Early Leisure Studies degrees were not required to compete with Sports Studies or Events Management; however, over the last fifteen years these courses have almost entirely replaced Leisure Studies courses. To put this into context a search for 'leisure' on the UCAS 
website at the end of 2015, returned 91 providers of Foundation, HND or degree level courses in 'leisure'. In many cases each institution provided more than one course so the number of courses available far exceeded the number of providers. Of those, only ten included 'leisure' in their title, and usually as part of a hybrid course, for example 'Management, Leadership and Leisure' (University of Manchester), 'Business and Management with Leisure and Tourism' (Edge Hill University). As at June 2016 there was only one 'Leisure Management' degree and not a single Leisure Studies programme. It is important to note that the UK is not an isolated case. In several countries where Leisure Studies has been established there has been a similar trend (see Henderson, 2010; Rowe, 2002; Shaw, 2000 for discussions on the USA, Australia and Canada respectively).

\section{The effects of neoliberal approaches on Higher Education and their impact on Leisure Studies}

The decline of Leisure Studies within UK HE institutions has occurred in the context of a trend in which successive UK governments have presided over an ideologically-driven restructuring of HE in which social models of provision have been replaced by an Americanised, consumerist market-led approach (Palfreman and Tapper, 2016). Neoliberalism is a value system in which the economic has replaced the intellectual and political and in which the competitive, rational individual predominates over the collective (Phipps and Young, 2015). Within this framework HE has been instrumentalised as a source of skills supply, 'with universities located as servants of the 'knowledge economy' and learning replaced by a concern with 'outcomes" (Phipps and Young, 2015: 306). Critical of this model for HE, Giroux (2014) goes as far as to suggest that neoliberalist dogmas are currently waging "war" on the idea of the university as a knowledgeproducing, and inherently social and critical space. For Giroux, corporate interests dictate the shape and style of degree-level programmes which, according to Andrews et al., (2013: 336) 'destabilizes the possibilities for higher education as a site of intellectual advancement, social justice, and critical and autonomous thinking.' An attendant result, according to Phipps and Young (2015), is that 'The academic has been redefined as the dispenser of a commodity...a rather corrupted teaching relationship which plays out in workplaces in which collegial democracy has made way for top-down managerial control' (p.306). Being an academic is tied to both teaching and research, although the differential status of these two core activities is widely acknowledged; both in terms of the HE institutions themselves (e.g., Russell Group vs 'new') and the courses being taught. Archer (2008) notes how academics report feeling under pressure to 'produce' and to achieve more in all facets of their roles - higher NSS results, more income generation, greater quantity of journal articles in higher ranked journals (what Silk et 
al., 2015 refer to as being 'calculable') - and express insecurity about the prospect of underperformance in any of these areas.

In terms of Leisure Studies, under added pressure from successive governments, HE institutions have sought to respond to the increased 'demand' from employers by developing 'specialist' courses in Sport, Events, Hospitality and Tourism. In turn, the most convincing knowledge claims are those that the market determines are the most performatively efficient, and everything, including leisure, has to be judged by its market value (Rose and Dustin, 2009). On the one hand, because of the expansion and proliferation of leisure industries over the past twenty years, some sub-fields within Leisure Studies - such as those mentioned above - have been significant beneficiaries of this market-led, 'widening participation' agenda. On the other hand, however, concurrent to the negative impact of the financial crisis of 2008 on the demand for graduate labour, there has been an over-production of skilled-knowledge workers and workready graduates who are often unable to find employment in the sector they were trained to enter (Tymon, 2013). Far from tempering the expectations of leisure graduates, students are, given the increase in UK university tuition fees and greater competition for a reduced number of well-paid service-based jobs, shaped evermore by enduring discourses of neoliberalism; adopting consumer mind-sets and demanding their degree course is a quality 'product'.

In response to a crisis of over-supply/under-demand, HE institutions have begun to place greater emphasis on concepts such as, 'the student experience' and 'employability' (Stone, Berrington and Falkingham, 2014). The link between education and employability is of particular importance in current government policy and strategic thinking in HE management. Cole and Tibby (2013) outline the six most desirable graduate attributes as: (1) oral communication; (2) teamwork; (3) IT skills; (4) problem solving; (5) time management; and (6) literacy and numeracy skills. Critical thought, one of the founding principles of Leisure Studies, is conspicuously absent. As Roberts (2016) notes, a business culture has replaced the service ethic of the voluntary and public sectors of leisure and they too have been drastically re-moulded in terms of the market. Leisure education is thus increasingly acquiring a primarily economic instrumentality which, according to Giroux (2010),

strips education of its public values, critical contents and civic responsibilities as part of its broader goal of creating new subjects wedded to the logic of privatization, efficiency, flexibility, the accumulation of capital and the destruction of the social state. (cited in Silk et al., 2015: 799)

To this end, the fragmentation of Leisure Studies and the reduction of degree courses with 'leisure' in the title is inevitable insofar as economic forces are demanding that subject 
fields 'rebrand' themselves in a number of different guises in order that their courses provide employers with sector-trained graduates - not necessarily critical thinkers.

\section{Method}

The Higher Education Academy's 'Teaching and Learning in the Disciplines' project, launched in 2015 , aimed to identify key themes and issues in curriculum planning and delivery in the social sciences and the research for this article deals exclusively with that element devoted to Leisure Studies. Twenty three learned societies, including the Leisure Studies Association, participated in the study, which produced a national report on HE pedagogy (Bulman, 2015). ${ }^{2}$ The project addressed the following questions:

1. What issues preoccupy higher education academics, particularly in their teaching and facilitating of student learning in their disciplines?

2. How are these challenges likely to evolve over time?

3. What particular issues confront academic teachers in different disciplines?

4. What can the HEA, professional bodies and learned societies do to help? The research for this article focused on the third of these questions. Data were collected using the guidelines provided by the HEA which suggested the use of focus groups academic staff involved in Leisure Studies throughout the UK. Three focus groups were conducted in, respectively, Scotland, Northern England and Southern England. These areas were selected because they had a strong tradition of the provision of Leisure Studies programmes and the availability of participants. It is not our intention here to determine whether regional differences exist; the situation facing Leisure Studies is a national (even international) problem and is unlikely to demonstrate regional peculiarities. Nineteen participants were invited from different HE institutions, all of whom were currently teaching/researching Leisure Studies. Each focus group included participants from a number of different HE institutions; a majority were Lecturers or Senior Lecturers, with a smaller number of Principal Lecturers, Readers, Professors and PhD students. 13 were male and 6 were female. Their experience of teaching and researching Leisure Studies varied from a few years to several decades. The inclusion of participants with varied lengths of experience was important in order to capture the longerterm effects of the changes outlined above. Participants were drawn from a wide range of course provision which included Sport Sociology, Sport History, Physical Education, Outdoor Adventure, Football Studies, Events Management and Sports Events Management. Interestingly, only one respondent self-identified as a 'Leisure Studies' scholar. 
A distinction was drawn between 'leisure-specific' and 'leisure-based' degree programmes. Leisure-specific referred to programmes with a core emphasis on concepts, philosophies and practices of leisure, for example Leisure Studies or Leisure Management, whereas leisure-based referred to those in which leisure theory was one specific facet of their theoretical construction, for example, Tourism or Events Management (see Aitchison, 2006; Rojek, 2014). Such a differentiation was necessary given the reported influence of the latter on the decline of the former. As demonstrated below, participants were keen to point out the often conflicting relationship between the two. Focus groups were facilitated by different individuals in each region. To ensure consistency of approach the HEA provided group facilitators with a script of essential questions/themes but also encouraged wider explorations. Each focus group lasted between 90 minutes and two hours; all were digitally recorded, transcribed verbatim and, as recommended by the HEA, thematically analysed against the research questions above. The sections that follow report participants' perceptions of the position and status of Leisure Studies in UK HE curricula.

\section{Relevance and fragmentation of Leisure Studies}

When asked to define 'Leisure Studies', the majority of respondents felt that the subject field was amorphous and indeterminate and embraced a series of other sub-fields. As one respondent commented, Leisure Studies was a complex entity:

... if you think about the Leisure Studies Association and the disciplines that converge to form that, it's broad ... History, Sociology, Politics, Tourism, Events, Hospitality ... coming from different fields.

There was an overall consensus that whilst a majority of leisure scholars would accept that Leisure Studies was necessarily diverse, it nevertheless remained misunderstood, particularly among senior managers. Reflecting on his institution, one participant commented:

[...] we think about it quite narrowly ... it [Leisure Studies] would traditionally be seen as 'over there' - that's the way Leisure Studies is wrapped up and packaged and perceived here.

As noted above, Leisure Studies courses have faced numerous challenges in terms of their rationale and content. The growth of sport-related (primarily in the Sport Sciences), and Events Management degrees has critically undermined the status and provision of Leisure Studies degrees. This decline was discussed at length and was most commonly attributed to the emergence of complementary sub-fields which quickly became direct competitors. One participant commented in detail on this: 
When I started working here some of the new courses such as Sport Business Management, Sports Marketing, had spun off from that main [Leisure Studies] course. The problem with Leisure Studies here is that it's seen other courses emerge in the portfolio that are actually direct competitors. So where does leisure go? The decision was made here to make Leisure Studies something more sociological, so the management stuff disappeared. It wasn't because we didn't think management was important for our students, rather because there was a management option and a marketing option. How does Leisure Studies survive under that?

The rising popularity of sport-based degree programmes was consistently identified as a threat to the legitimacy of Leisure Studies:

Sport as a cultural and social practice is one of the biggest threats to Leisure Studies because it undermines [it] because it is so far in the ascendancy that it undermines any other kinds of leisure practices ... Sport, potentially, depresses other forms of leisure, although it is itself a form of leisure, but somehow it sits in this privileged position.

The perception that sport degrees were in some way institutionally privileged was shared by several respondents who believed this was evidence of a consumerised curriculum which demanded a re-branding of Leisure Studies courses as sports courses. Spracklen articulates this when arguing that new courses 'fitted more easily the interest in sport among the prospective students, sounded better to parents concerned with employability, and were easier to market by university managers ...' (Spracklen, 2014: 22). Another respondent concurred:

Sport has got the [student] numbers so it has got the power. It's a propagating cycle isn't it, so gradually the smaller voices get smaller and less well heard. This university is a primary example of power ... it's who has got the loudest voice.

The centralisation of 'sport' in leisure-based learning was also noted by a respondent, who described her recent experiences of the impact of marketing pressures on the development of a historically leisure-based degree into one that was now more sport oriented:

We have positioned sport as the priority, and even though we have tried to keep the word 'leisure' in module titles and we will still speak about leisure ... I just feel sad that we haven't been able to "big it up" ... but because of the market we have had to put sport at the forefront. (original emphasis)

This testimony resonates strongly with Davies et al's (2006: 308) argument that the effect of neoliberal discourse on academic subjects has been 'to transform them, to transform what is 
thinkable, and to transform the nature of academic work'. In short, Leisure Studies is another victim of what Slaughter and Rhoades (2004) have called 'academic capitalism'; it is yet another example of the subordination of social enquiry to capital in the form of 'bums on seats'. It should be noted again here that Leisure Studies is not unique in this respect. Silk et al. (2015) for example, demonstrate how a hierarchy exists even within the multi-disciplinary field of 'sport' where
"sport" departments tend to be either exclusively bio-science focused or unapologetically bio-science centric (the social sciences and humanities being begrudgingly tolerated, but habitually under-funded and under-supported, and needing to "prove" their worth and often "conform" to prescribed, neo- "legitimate," standards.
Leisure Studies has always been a multi-disciplinary subject field. Whereas some respondents perceived this as a strength - demonstrating its vibrancy - others felt it affirmed notions of fragmentation, incoherence and irrelevance:
The university thinks that Leisure Studies is just a rag taggle of stuff that isn't Sport and it isn't Events ... 'leisure' (in a mocking tone), it's just the thing in the middle that's something to do with active recreation.

Andrews et al., (2013) noted similarly in their examination of Kinesiology as a subject area in North America, in which they state: 'this [Kinesiology] is a far from integrated field ... in its current iteration, kinesiology is a field fraught with hyperfragmentation and hyperspecialization in which there is instantiated an epistemological hierarchy...' (p.335).

There was further belief that the word 'leisure' no longer held cogency with prospective students and employers. This may be equally true of 'studies' which to some symbolises intellectual imprecision and vagueness. In contrast, descriptors such as 'science', 'management' and 'business' appear more focused and applicable to the market and thus, are more appealing to students and employers. This view was captured by a respondent who commented that 'leisure' was too broad for students to identify with, especially when compared to other more self-explanatory subjects:

Leisure is ... such a broad concept, no one student or course probably identifies that clearly. The students I teach are all about a particular part of the sector ... they wouldn't recognise leisure as being relevant to them. It's lost salience; it's almost antithetical to getting a job. So we don't offer Leisure Studies anymore.

The suggestion of 'relevance' was powerful and brought into focus the relationship between HE, vocational learning and employability (discussed below). We are keen to point out however that 
this contradicts the notion that 'leisure' pervades HE in a variety of guises, which is an emergent theme we documented earlier in the paper. Simply put, leisure is undeniably relevant. In order to reclaim the ' $\mathrm{L}$ ' word from the fractious and individualistic tendencies of neoliberalisation then, those invested in the Leisure Studies tradition must better promote the values of the field by emphasising the benefits of collectivism, community-centredness and knowledge transfer amongst scholars and practitioners from a number of different disciplines and sub-fields.

Another channel through which leisure scholars are able to combat the decline in Leisure Studies degree programmes in the UK, was the belief that scholars of leisure retain academic integrity through the inclusion of the term 'leisure' in the title of REF Unit 26:

Leisure Studies survives here because we (leisure scholars) are part of the REF. Because it's part of the REF people think we are significant enough to be employed. But if that goes, if Leisure Studies merged with Events and Tourism and went into another REF unit that would be the end of Leisure Studies.

Moreover, it was noted that whilst the visibility of Leisure Studies courses was not overly pronounced, academic research remained strong:

If you think about journal publications and the recent REF, there's a wealth of people who were entered under Unit 26 who were writing and researching around leisure and their work has not only got national recognition, its international and world leading so there's an extensive body of material that is cutting edge.

The health of any academic field must be judged, in part at least, on the body of research underpinning and emerging from it. There is a long history of Leisure Studies research, which is reinforced contemporaneously by the strength and popularity of journals like Leisure Studies, Annals of Leisure Research, Leisure Sciences, World Leisure Journal and Leisure/Loisir. However, we warn against judging the viability of Leisure Studies through volume of publications alone given this has limitations, as well as strengths, in terms of its application to teaching. In other words, the perception that leisure was well represented in REF 2014 was based on an assumption that submissions on Sport, Tourism and Events are considered to be constituents of leisure. If we adopt the view of Aitchison (2015) above, the strength of leisure in REF 2014 was not nearly as strong as respondents in this research suggested. Simply put, if there are no degree programmes, leisure-related research becomes, outwardly at least, less legitimate under the logic of a market-based system that reinforces research-informed teaching.

\section{Vocational learning and the Higher Education curriculum}


Higher Education in the UK is increasingly shaped by a culture of audit and quantification. According to MacRury (2007), its key features include outcome-based assessment systems for research productivity, student employability, student retention, arduous external assessment systems and the publication of miscellaneous league tables. Increasingly, academic curricula, that is, a set of educational practices organised around teaching and learning have become a vehicle for practical experiences believed to contribute to enhanced employability. It is not suggested that these objects are mistaken; however, economic pressures have created tensions between different pedagogical approaches. The decline in Leisure Studies courses and the growth of seemingly more vocational courses such as Events Management, has forced advocates of a more critically academic Leisure Studies on to the defensive (Harris, 2015). Writing on the development of Tourism degrees for example, Tribe (2002) argues in favour of balancing vocational and academic aims, concluding that there should be no overriding principles for ordering tourism curricula. As such it becomes difficult to assess the relative balance of academic and work-related skills (Fidgeon, 2010). In the case of Events Management degrees for instance, employers expect HE institutions to provide students with more opportunities to apply skills and knowledge developed in the classroom to 'real' workplace situations. Consequently, educators and administrators in Events Management education have worked hard to enhance cooperation with industry partners, providing work-related courses. Some have argued that this has been to the academic detriment of these degrees (see Rojek, 2014).

The current research epitomised these tensions. There was general agreement that embedding vocational competency was important to the enhancement of graduate competitiveness in the marketplace, but there was also concern that this might undermine traditional notions of 'higher' learning. There was a popularly held view that leisure courses were under threat from university marketing executives who privileged outcomes emergent from neoliberalist discourse - such as 'graduate competencies' and 'employability' - above critical thinking. It was, for example, commented upon that management-based subjects were considered more important than social and historical subjects and were consequently articulated more effectively in terms of employment. As suggested by these respondents:

There is, in some ways, more legitimacy to the management side to the study of leisure compared to the sociological and historical ... and I think that we feel pressure, well I feel pressure, on that side to stress the management worth of it and how this will help you in a job rather than just develop your knowledge. 
I used to sell the sports degree as a degree in thinking, not necessarily a career, but a degree in thinking. I think we have lost that. I think we have gone down this vocational trading route.

Tensions over the role and purpose of degree level study were fiercely debated. Balancing the development of practical-skills with the academic rigour of a traditional university education was a task some respondents expressed concern about. It was acknowledged that academics are expected to embed their own research into teaching and for those in the research who were research-active, this was already standard practice, but for those who were not, this was perceived as a challenge. It was acknowledged that universities are expecting more staff to be research active, to publish, to bring in external money, all of which contribute to researchinformed teaching. Some respondents, like the one below, believed that these priorities towards research-informed teaching have contributed to growing conflict between those who were frequently referred to as the 'academics' or the 'practitioners', teaching in these areas:

I think around this table we have a bunch of people who are more critically informed, more critically orientated. I mean, maybe people come from sociological backgrounds or from policy backgrounds, but there are still an awful lot of events academics, in particular, who came in through the practitioner route and ... for who the idea of research-led teaching is just a fancy way of saying "lots of ideas but no actual clue how to do the job".

Clearly, this issue goes beyond individual teaching philosophies; extending to consider what the roles of universities are in terms of enabling and supporting academics to undertake research that they want to do and is perceived to be of academic and practical value. While conflict between staff who favour a vocational emphasis and others who prioritise critical academic forms of teaching and learning was revealed, the two approaches were not considered to be mutually exclusive.

As educators, as well as researchers, we are reminded of the importance of transferring knowledge from research into teaching. We acknowledge that many leisure-related university courses (e.g., Events Management, Tourism and Sports Development) are justifiably, vocational and practically orientated. Harris (2015: 2) suggests we move away from the twin concepts of 'academic' and 'vocational' learning. He considers that teaching and learning should focus on providing 'threshold concepts'; that is, 'there is no necessary reversion to a simple demand for more 'academic' as opposed to more 'vocational' courses ... acquiring powerful knowledge should be the focus of any university course'. Indeed, to advance a holistic understanding of Leisure Studies we need multiple knowledges, 'truths' and understanding (Silk et al., 2015). 
Many respondents were already engaged in this kind of research/teaching and, therefore, the challenge for leisure scholars moving forward must be to make this case more strongly to an array of different audiences, including governmental agencies, local/national enterprises and senior management across the HE sector.

One way Leisure Studies might address this point is to better embrace an interventionist agenda regarding matters of diversity and inclusion. Leisure has previously been effective in identifying such injustices however it has been less successful in combating them (Stewart, 2014). From this position making the case for the social relevance of Leisure Studies is not difficult. We write in a field where there are repeated observations about the lack of minoritised people in managerial and coaching roles in professional sport (Fletcher et al., 2014; Fletcher and Hylton, forthcoming), protests about the whiteness of film and media (Lawrence, 2011, 2014), shortage of roles for women and people with disabilities in theatre, film and TV, allegations of sexism in the music industry and ageism in the broadcast media and point blank refusals to accommodate gay couples in a whole host of leisure activities (Long, Fletcher and Watson, forthcoming, 2017). And, given neoliberalism - as a political ideology - has embraced an equality agenda of sorts, even if this embrace is rooted in a belief diversity has a commercial value, Leisure Studies is well placed to contribute to contemporary social and cultural debates as well as to be of value to policy makers.

\section{Discussion and conclusions}

Whereas other research has focused on student testimony (Elkington, 2013) or has engaged in discussion without input from primary data (Harris, 2015; Henderson, 2010) the research reported here is based on the views of academic staff in the field of Leisure Studies. Their grounded experiences provided crucial insights to the position of Leisure Studies in the UK curricula. Leisure Studies appears to be confronted by two principal challenges. Firstly, to (re)establish its importance and relevance to other disciplines and subject fields within the social sciences; and secondly, to connect leisure research more effectively to leisure practice and management.

The decline of Leisure Studies as a discreet degree programme certainly does not signal its demise; there is in fact increased interest in leisure in some other subject areas. Indeed, to reduce the significance of Leisure Studies to its visibility in degree titles would do a disservice to Leisure Studies as a field. An alternative approach would be to consider the extent to which Leisure Studies has established itself as a field of social science; were it to demonstrate this 
more effectively, its importance would reside in its contribution to discourses across the social sciences and its perceived value to academics in other disciplines and subject fields.

Many of the participants in this research attributed the decline in Leisure Studies provision in HE curricula to the fragmentation of the field brought about by neoliberal market forces - i.e., an increased thirst for vocational courses with a priority for employability, rather than academic rigour. According to Back (2016), this is unsurprising given the commodification of HE. And, he writes, herein lies an important paradox, that is,

some of our most clearly held educational values are in direct conflict with the economic and practical conditions within which teaching takes place. As a result, the pressure and temptation to simplify the curriculum and make courses less demanding and more 'student friendly' militates against the commitment to spend time with difficult ideas. (p.49)

Moreover, Elkington (2013: 450) argues that, as leisure researchers and educators remain wedded to their parent disciplines, wherein 'they are encouraged to uphold the importance and value of leisure and not be self-critical, to maintain the status quo', the study of leisure has arguably become increasingly insular; maintaining a preoccupation with traditional theorybased research. For Elkington, this represents a self-perpetuating cycle whereby 'much of what has been written about leisure can be a barrier in preventing engagement with the actual experiences of modern leisure' (ibid.). Henderson (2010) suggests similarly that perhaps a disconnect lies with educators and researchers who have become so specialised that they no longer see a common identity and mission related to Leisure Studies.

The challenge then becomes one of relevance: determining the core mission, place and value of Leisure Studies and communicating these to other subject fields and wider society. Leisure Studies would benefit from being better integrated with its parent disciplines in the social sciences and more strongly connected to other learned societies and professional bodies. This would necessitate some recognition of its shortcomings, but not a complete reconceptualisation as others have suggested (Spracklen, 2014). To this end, Evans (2014) proposes the need for more academics to engage in 'ideational border crossings' to advance thinking in different subjects and disciplines. Those subjects that may be under threat in the current climate of HE (like Leisure Studies) may benefit from exploring opportunities to collaborate with those from outside of their immediate subject area. Those working in Leisure Studies for example, might pursue how best to relate it to Physical Activity and Health; areas with political support from HE institutions and from central government. In his defence of the Sociology of Sport, for example, Bairner (2012: 115) advocates that 'almost anything that helps 
us to break away from talking among ourselves and allows us to enter into dialogue not only with mainstream sociologists but even natural scientists is to be encouraged.' The same might be said of Leisure Studies. This would require caution because, unless leisure scholars can articulate what makes Leisure Studies distinct from other fields it is hard to justify its existence, but as Evans (2014: 11) emphasises, it need not involve relinquishing commitments to parent disciplines but rather mutual engagement with other subject fields and disciplines, with a continuity of strong subject-specific attachments and allegiances while simultaneously searching for heightened and shared understandings of ideational common ground. A case in point is research funding. The UK Research Councils do fund research that is leisure oriented, they are just not named as such, rather they go under the banner of 'the arts', 'media', 'heritage' and 'culture'. Over twenty years ago Rojek (1995) referred to the idea of 'decentring leisure'; advocating for leisure researchers to become less 'leisure-centric'. Rojek's suggestion remains as important as ever. If Leisure Studies is to continue to be seen as socially useful, teachers and researchers need to direct their attention outwards: to the pressing issues at any given time, and the potential role of leisure in these, rather than taking leisure as the necessary starting point. In short, Leisure Studies arguably suffers from a crisis of representation, as opposed to a crisis of relevance.

\section{Acknowledgments}

The Higher Education Academy supported this project as part of its programme of research with learned societies and professional bodies mapping the current range of disciplinary and subjectspecific issues in higher education teaching and learning. The facts presented and views expressed in this article are, however, those of the authors and participants in the research not necessarily those of the HEA.

\section{References}

Aitchison, C. (2006). The critical and the cultural: Explaining the divergent paths of Leisure Studies and tourism studies. Leisure Studies, 25, 417-422.

Aitchison, C. (2015). Creating Insight, Impact and Influence: how research assessment (re)defines knowledge, policy and practice. Paper presented to the Leisure Studies Association conference, Bournemouth University: July 7.

Andrews, D. (2006). Leisure Studies: Progress, phases and possibilities - An interview with Alan Tomlinson. Leisure Studies, 25, 257-273. 
Andrews, D.L., Silk, M., Francombe, J. and Bush, A. (2013) McKinesiology. The Review of Education, Pedagogy, and Cultural Studies, 35,335-356.

Archer, L. (2008). The new neoliberal subjects? Young/er academics' constructions of professional identity. Journal of education policy, 23(3), 265-285.

Back, L. (2016) Academic Diary: Or why Higher Education still matters. London: Goldsmiths Press.

Bairner, A. (2012). For a sociology of sport. Sociology of Sport Journal, 29, 102-117.

Bramham, P. (2006). Hard and disappearing work: Making sense of the leisure project. Leisure Studies, 25, 257-273.

Bulman, S. (2015). Teaching and learning in the disciplines: an HEA-funded project [online] available from https://www.heacademy.ac.uk/sites/default/files/teaching-learning-in-thedisciplines-summary.pdf [accessed November 2, 2015].

Carrington, B. (2015). On race and diaspora. International Review for the Sociology of Sport, 50, 391-396.

Cole, D. and Tibby, M. (2013). Defining and Developing Your Approach to Employability, [online]. Available from: http://www.heacademy.ac.uk/assets/documents/employability/Employability framework.pdf (Accessed: 01 May 2015).

Davies, B., Gottsche, M. and Bansel, P. (2006). The rise and fall of the neoliberal university. European Journal of Education, 41, 305-319.

Elkington, S. (2013). Ways of seeing degrees of leisure: from practice to pedagogy. Leisure Studies, 32, 447-461.

Evans, J. (2014). Ideational border crossings: rethinking the politics of knowledge within and across disciplines. Discourse: studies in the cultural politics of education, 35, 45-60.

Fidgeon, P. (2010). Tourism Education and Curriculum Design: A Time for Consolidation and Review? Tourism Management, 31, 699-722.

Fletcher, T., Piggott, D., North, J., Hylton, K., Gilbert, S. and Norman, L. (2014) Exploring the barriers to South Asian cricket players' entry and progression in coaching. London: England and Wales Cricket Board. Available from: http://eprints.leedsbeckett.ac.uk/782/3/LMU\%20\%20South\%20Asian\%20Cricket\%20Coach\%20Project\%20-\%20Final\%20Report\%20-

\section{\%20Draft $\% 202 \% 20-\% 2014-11-2014 . p d f$}

Fletcher, T. and Hylton, K. (Forthcoming, 2016) 'Race', 'whiteness' and sport. In J. Nauright. And D.K. Wiggins (eds) Routledge Handbook of Race, Ethnicity and Sport. Abingdon: Routledge. 
Fletcher, T., Snape, R., Carnicelli, S. and Lawrence, S. (2015). Teaching and learning in the disciplines: Leisure Studies. Institute for Sport, Physical Activity and Leisure, on behalf of the Higher Education Academy. Available from: http://eprints.leedsbeckett.ac.uk/1761/. Giroux, H. (2014) Neoliberalism's war on higher education, Chicago, IL: HaymarketBooks. Harris, D. (2015). Threshold concepts in teaching Leisure Studies, Leisure Studies, DOI: 10.1080/02614367.2015.1052837.

Henderson, K.A. (2010). Leisure Studies in the $21^{\text {st }}$ century: the sky is falling. Leisure Sciences, 32, 391-400.

Kennedy, E. and Pussard, H. (eds.) (2006). Defining the field: 30 years of the Leisure Studies Association: Brighton: Leisure Studies Association.

Lawrence, S. (2011) Representation, Racialisation and Responsibility: Male athletic bodies in the (British) sports and leisure media. In: Watson B and Harpin J (eds) Identities, Cultures and Voices in Leisure and Sport. Eastbourne: Leisure Studies Association, 109-124.

Lawrence, S. (2014) Racialising the "great man": A Critical Race study of idealised male athletic bodies in Men's Health magazine. International Review for the Sociology of Sport.

Long, J., Fletcher, T. and Watson, R. (forthcoming 2017). Introducing sport, leisure and social justice. In J. Long., T. Fletcher and R. Watson (eds) Sport, leisure and social justice. London: Routledge.

MacRury, I., (2007). Institutional creativity and pathologies of potential space: the modern university. Psychodynamic practice, 13, 119-140.

Page, S.J., and Connell, J. (2010). Leisure: An introduction. London: Prentice-Hall.

Palfreyman, D. and Tapper, T. (2016) The marketization of English higher education and the financing of tuition fees. London Review of Education, 14, 47-55.

Parker, S. (1971). The future of work and leisure. London: MacGibbon and Kee.

Phipps, A. and Young, I. (2015) Neoliberalisation and 'Lad Cultures' in Higher Education.

Sociology, 49(2), 305-322.

Pike, E.C.J., Jackson, S.J. and Wenner, L.A. (2015). On the trajectory, challenges and future of the field. International Review for the Sociology of Sport, 50, 357-362.

Roberts, K. (1970). Leisure. London: Longman.

Roberts, K. (2014) Leisure Studies and the Sociology of Sport, in R. Giulianotti (ed.) The Routledge Handbook of the Sociology of Sport. London: Routledge.

Roberts, K. (2016). The Business of Leisure: Tourism, Sport, Events and Other Leisure Industries. Basingstoke: Palgrave Macmillan.

Rojek, C. (1995). Decentering leisure. London: Sage Publications. 
Rojek, C. (2014). Global Event Management: a critique. Leisure Studies, 33, 32-47.

Rose, J. and Dustin, D. (2009) The neoliberal assault on the public university: the case of recreation, park and leisure research. Leisure Sciences, 31, 397-402.

Rowe, D. (2002). Producing the crisis: the state of Leisure Studies, Annals of Leisure Research, 5, $1-13$.

Shaw, S.M. (2000). If our research is relevant, why is nobody listening? Journal of Leisure Research, 32, 147-151.

Silk, M., Francombe-Webb, J., Rich, E. and Merchant, S. (2015) On the transgressive possibilities of physical pedagogic practices. Qualitative Inquiry, 21(9): 798-811.

Slaughter, S and Rhoades, G. (2004) Academic capitalism and the new economy: Markets, state, and higher education, Baltimore: JHU Press.

Sparkes, A.C. (2013). Qualitative research in sport, exercise and health in the era of neoliberalism, audit and New Public Management: understanding the conditions for the (im)possibilities of a new paradigm dialogue. Qualitative Research in Sport, Exercise and Health, $5,440-459$.

Spiers, A. and Walker, G. J. (2009). The Effects of Ethnicity and Leisure Satisfaction on Happiness, Peacefulness, and Quality of Life. Leisure Sciences, 31, 84-99.

Spracklen, K. (2014). Leisure Studies education: Historical trends and pedagogical futures in the United Kingdom and beyond. Journal of Hospitality, Leisure, Sport \& Tourism Education, 15, 2023.

Stewart, W. (2014) Leisure research to enhance social justice. Leisure Sciences, 36 (4) 325-339. Stone, J., Berrington, A. and Falkingham, J. (2014). Gender, Turning Points, and Boomerangs: Returning Home in Young Adulthood in Great Britain. Demography, 51, 257-276.

Such, L. (2013). Little leisure in the Big Society. Leisure Studies, 32, 89-107.

Tribe, J. (2002). The philosophic practitioner. Annals of Tourism Research, 29, 338-357.

Tymon, A. (2013). The student perspective on employability. Studies in Higher Education, 38, 841-856.

\footnotetext{
${ }^{1}$ Following on from the 2009 Research Assessment Exercise (RAE) leisure was initially dropped from the unit of assessment for the 2014 REF exercise. A number of academics were involved in championing the right of leisure studies to be included.

${ }^{2}$ The report submitted on behalf of the LSA (Fletcher et al., 2015) is available from:

http://eprints.leedsbeckett.ac.uk/1761/
} 